(2) Open Access Full Text Article

REVIEW

\title{
Improving Medical Education in Hematology and Transfusion Medicine in Canada: Standards and Limitations
}

\author{
Marissa Laureano' \\ Siraj Mithoowani ${ }^{2}$ \\ Eric K Tseng ${ }^{3}$ \\ Michelle P Zeller ${ }^{4}$ \\ 'Department of Medicine, Department of \\ Pathology and Molecular Medicine, \\ McMaster University and Canadian Blood \\ Services, Hamilton, ON, Canada; \\ ${ }^{2}$ Division of Hematology \& \\ Thromboembolism, Department of \\ Medicine, McMaster University, \\ Hamilton, ON, Canada; ${ }^{3}$ Division of \\ Hematology/Oncology, St. Michael's \\ Hospital, University of Toronto, Toronto, \\ ON, Canada; ${ }^{4}$ Division of Hematology \& \\ Thromboembolism, McMaster Centre for \\ Transfusion Research and Canadian Blood \\ Services, Hamilton, ON, Canada
}

Correspondence: Michelle P Zeller Hamilton Health Sciences Centre, HSC $3 \mathrm{H} 54,1200$ Main Street West, Hamilton, ON, L8S 4KI

Email zeller@mcmaster.ca

\begin{abstract}
The paradigm of medical education is evolving with the introduction of competency-based medical education (CBME) and it is crucial that residency programs adapt. In this paper, we provide an overview of the current status of medical education in Hematology in Canada including models of training, assessment methods, anticipated challenges, and the effects of the COVID-19 pandemic. We will also discuss additional training that can be pursued after a Hematology residency, with a particular focus On Transfusion Medicine as it was one of the first programs to implement a competency-based curriculum. Finally, we explore the future directions of medical education in Hematology and Transfusion Medicine.
\end{abstract}

Keywords: medical education, Hematology, competency-based

\section{Introduction}

This paper addresses multiple aspects of Hematology medical education in Canada. We explore current curricula, training opportunities after residency, and the transition to competency-based medical education (CBME). CBME emphasizes knowledge application and aims to foster learner's abilities. ${ }^{1}$ This is in contrast to traditional time-based programs which have a greater emphasis on knowledge acquisition. Key terms and definitions have been highlighted in Table 1 and these concepts will be further elucidated throughout the paper. The aim of this descriptive paper is to share our experience with Hematology education in the Canadian context. We also aim to link theory to practice and examine both the practical and theoretical challenges of implementing CBME.

\section{Current Models of Training in Hematology}

The current structure for Hematology training in Canada follows a traditional model of medical education with rotations that are time and process-based and occur over a 2-year period. Entrance into one of 14 accredited Hematology Subspecialty Residency program across the country requires certification in Internal Medicine. As of 2021, there are 32 Hematology residency positions funded by the Ministry of Health. Additional positions may also be available through external funding. Minimum training requirements include successful completion of the following rotations: 
Table I Definition of Terms

\begin{tabular}{|c|c|}
\hline Term & Definition \\
\hline Competence & $\begin{array}{l}\text { "Habitual and judicious use of } \\
\text { communication, knowledge, technical } \\
\text { skills, clinical reasoning, emotions, values } \\
\text { and reflection in daily practice for the } \\
\text { benefit of the individual and community } \\
\text { being served" } 42\end{array}$ \\
\hline Competencies & $\begin{array}{l}\text { Elements of competence such as } \\
\text { knowledge, technical skills, and reasoning. }\end{array}$ \\
\hline $\begin{array}{l}\text { Entrustable professional } \\
\text { activities (EPAs) }\end{array}$ & $\begin{array}{l}\text { A task that can be entrusted to a trainee } \\
\text { once they have obtained sufficient } \\
\text { competence. }{ }^{44}\end{array}$ \\
\hline Milestones & $\begin{array}{l}\text { Observable stages of development with } \\
\text { regards to a trainee's abilities. }\end{array}$ \\
\hline Assessment & $\begin{array}{l}\text { Examination and judgement of a trainee's } \\
\text { ability. }\end{array}$ \\
\hline Portfolio & A dynamic compilation of assessments. ${ }^{45}$ \\
\hline Evaluation & $\begin{array}{l}\text { Deliberate collection of information about } \\
\text { a training program to understand its } \\
\text { strengths and weaknesses. }\end{array}$ \\
\hline $\begin{array}{l}\text { Competence by Design } \\
\text { (CBD) }\end{array}$ & $\begin{array}{l}\text { An education model inspired by } \\
\text { competency-based medical education } \\
\text { (CBME). }{ }^{46} \text { It is supported by the Royal } \\
\text { College of Physicians and Surgeons of } \\
\text { Canada. As a hybrid model, it } \\
\text { incorporates both time and outcome- } \\
\text { based learning. EPAs and milestones form } \\
\text { the backbone of learning objectives within } \\
\text { CBD. }{ }^{46}\end{array}$ \\
\hline
\end{tabular}

- Clinical hematology (8 months)

- Pediatric hematology (1 month)

- Stem cell transplant (1 month)

- Laboratory exposure (6 months)

- Research or Quality Improvement (1 month)

- Clinical hematology, laboratory, research, or other relevant course of study (7 months)

Hematology is one of the few subspecialties that requires expertise in both clinical and laboratory medicine. Curriculum delivery, rotation supervision, and assessment are provided by physicians and allied healthcare professionals including technical specialists and laboratory technologists. The current Training Objectives ${ }^{2}$ set by the Specialty Standards Review Committee follow the CanMEDS Framework which consists of 7 domains:
Medical Expert, Communicator, Collaborator, Manager, Health Advocate, Scholar and Professional. ${ }^{3}$ All residency training programs in Canada are in the process of transitioning to a competency-based model of education. Implementation of Competence by Design (CBD) in Hematology will be implemented as of July 2022.

Given the broad and diverse nature of Hematology, there are disparities with regards to exposure to certain hematologic conditions. For example, not all centres have access to patients with hemoglobinopathies, while others do not have faculty members in other subspecialties within Hematology who can provide specific clinical opportunities and teaching. In addition, preparation for exams can be resource-intensive, especially for smaller programs. Since 2006, a National Hematology Resident Retreat has been organized to bring together Hematology trainees from across Canada. The retreat addresses certain content-area gaps and provides opportunity for mock exams and networking. The retreat is funded through sponsors and individual Hematology programs so that it is free of charge to the trainees. Educational activities include a mock oral examination, specialized workshops, expert lectures, and a morphology exam/review. There is also an online written exam completed just prior to the retreat.

The current model of Hematology training in Canada shares some similarities with programs in other countries. In Canada, the Royal College of Physicians and Surgeons of Canada (RCPSC) is the regulatory organization that oversees the credentialling of specialists. The United States has an analogous organization known as the Accreditation Council for Graduate Medical Education (ACGME). Both the RCPSC $^{2}$ and ACGME $^{4}$ establish objectives for Hematology training, emphasize direct observation, and suggest the use of competency committees. In addition, prior residency training (eg, internal medicine or pediatrics) is required in both countries before specialization in Hematology can be pursued. A unique aspect of Hematology training in the United States is the availability of combined Hematology/Oncology programs. In Canada, Hematology and Medical Oncology programs are typically separate. With regards to competency-based training, countries across the world including Canada, the United States, and the United Kingdom are moving towards CBME. ${ }^{5}$ Efforts are being made to increase the worldwide awareness of competency-based training and networks such as the International Competency-based Medical Education 
(ICBME) Collaborators aim to promote and advance CMBE implementation and scholarship. ${ }^{6}$

\section{Beyond the Hematology Residency: Additional Training}

To recognize advanced training that is completed after residency, the Area of Focused Competence (AFC) designation was created by the RCPSC in 2009. Specifically, AFC refers to "supplemental competencies that enhance the practice of physicians in an existing discipline, or a highly specific and narrow scope of practice that does not meet the criteria of a subspeciality". ${ }^{7}$

\section{Transfusion Medicine}

The Transfusion Medicine Fellowship is recognized as an AFC program and was the first fellowship program in Canada to adopt a competency-based curriculum. ${ }^{8}$ The training program is 1-2 years long; as of September 2021 there are three accredited programs in Canada (McMaster University, University of Toronto, and University of British Columbia). Trainees in the program must have RCPSC certification or an equivalent credential in Internal Medicine \& Hematology, Pediatrics \& Pediatric Hematology Oncology, Hematological Pathology, Anesthesiology, or General Pathology. Funding for the fellowship is provided by Canadian blood suppliers, Canadian Blood Services (CBS) and Héma-Québec (HQ), or through external sources such as governments outside of Canada. CBS also plays a key educational role for trainees by facilitating learning around multiple aspects of the blood system such as donor recruitment, blood product manufacturing, testing, utilization, and surveillance.

As part of a competency-based curriculum, trainees monitor their progress by keeping a portfolio. Completion of the portfolio requires the submission of a variety of documents such as case summaries, lab reports, reflections, and structured examinations. The RCPSC has also outlined goals of training for Transfusion Medicine and this document was last updated in 2018. Given the AFC Transfusion Medicine program is the first of its kind in Canada, a study is currently being carried out to examine how the competency-based assessment portfolio impacts acquisition of clinical competence in Transfusion Medicine. ${ }^{9}$

\section{Adult Thrombosis Medicine}

AFC accredited programs for Adult Thrombosis Medicine are offered at McGill University, McMaster University, and University of Ottawa. Programs range from 1-3 years in length depending on whether the applicant wishes to pursue graduate studies. Prior to matriculating, trainees must be certified in Internal Medicine or Emergency Medicine. For assessment, AFC Program Portfolio Milestones have been laid out. At McMaster University, additional feedback is obtained at the mid-point and end of each rotation.

The AFC Thrombosis program was started at McMaster University to provide greater structure to Thrombosis training given the multidisciplinary nature of the specialty, rapidly changing therapies and increasingly complex patient cases. The program is designed for physicians who want to focus their practice and potentially start a new Thromboembolism service at a hospital or clinic. Areas of uncertainty remain within advanced training programs in Thrombosis. Some programs continue to explore avenues to secure stable funding for trainees. In addition, given that the AFC designation for Thrombosis Medicine is relatively new, it is unclear how this may change credentialling requirements for non-AFC trained physicians who also intend to focus their practice in Thrombosis.

\section{Hematopoietic Stem Cell Transplantation and Cellular Therapy}

The newest Area of Focused Competence is hematopoietic stem cell transplant (HSCT) and cellular therapy. This was approved by the RSCPC in December 2017. As of 2021, no Canadian programs have undergone accreditation.

\section{Non-AFC Fellowships}

In addition to AFC fellowships, there are multiple other training opportunities after completion of a Hematology residency in Canada. Within the broad scope of malignant Hematology, there are fellowships in leukemia, lymphoma, myeloproliferative neoplasms, and multiple myeloma. Nonmalignant fellowships include bleeding disorders, hemoglobinopathies, and women's health. Some universities also offer Clinical Scholar positions which are pre-faculty appointments in which trainees can pursue additional post certification training. These fellowships all have varying structures, and the majority are time-based. A survey of Hematology program directors revealed varying availability of fellowships across Canada (see Figure 1).

\section{Current Methods of Assessment in Hematology Training Programs}

Assessment of competence is a critical component of any training program. However, the goals of assessment may 


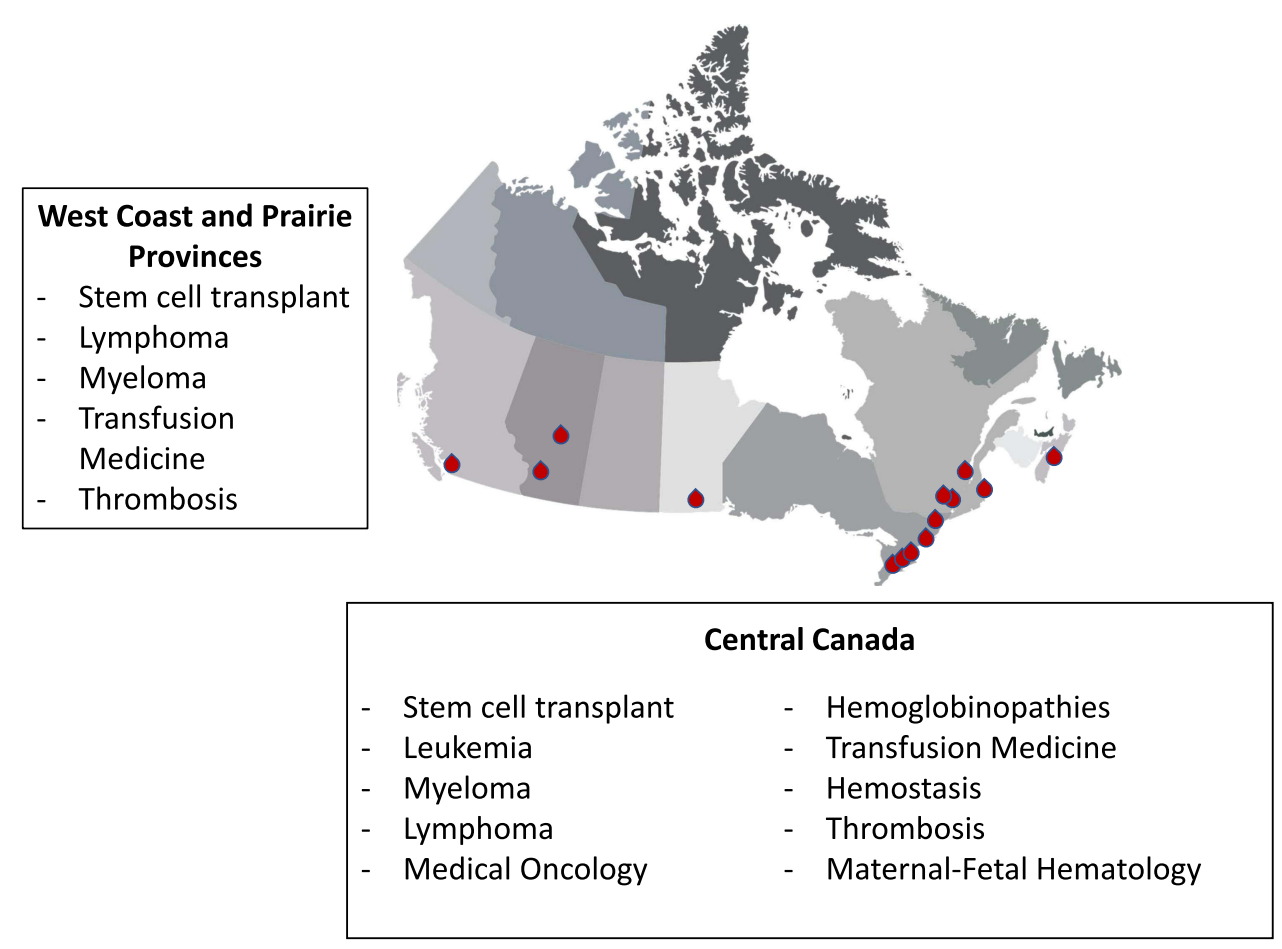

Figure I Availability of fellowship opportunities after Hematology training throughout Canada. The red markers denote the location of a Hematology residency program. Image available at https://pixabay.com/illustrations/map-canada-provinces-territories-2088308/. Licenced under the Creative Commons Attribution.

differ depending on whether a traditional or competencybased model of training is used. Traditional, time-based programs have typically viewed assessment as a way of determining whether learners have successfully completed the requirements of their training program. Progress in these programs is measured against specific outcomes - an assessment of learning. ${ }^{10}$ On the other hand, competency-based training programs view assessment as a means of driving learning - assessment for learning. ${ }^{11}$ Competency-based training often involves active trainee participation in seeking assessments, direct observation, and the frequent use of formative feedback. As programs shift from traditional to competency-based training, it is expected that methods of assessing trainee performance will also transition from assessment of learning to assessment for learning.

There are multiple theoretical benefits of a competencybased training curriculum such as improved accountability, flexibility, patient-centered competencies, and a greater emphasis on learner needs. In procedural specialties, the implementation of competency-based training was found to enhance procedural skills ${ }^{12}$ and cost-effectiveness. ${ }^{13}$ Some residents in a Canadian orthopedic surgery residency were also able to complete their program earlier through a competency-based curriculum. ${ }^{14}$ However, it is unclear whether the results of these studies can be applied to non- procedural specialties such as Hematology and Transfusion Medicine. There are few data evaluating whether CBME ultimately improves patient outcomes, so this remains an important area for future research.

Within time-based Hematology training programs, assessment methods can be conceptualized and organized through the lens of Miller's Pyramid. This is a four-tiered framework that distinguishes lower levels of clinical competence ("knows," "knows how") from higher levels of proficiency ("shows how," "does"). ${ }^{15}$ In Table 3, we show examples of specific assessment methods within Hematology that may represent different levels within Miller's Pyramid. Of note, both traditional- and competencybased models incorporate multifaceted programs of assessment that span the breadth of levels of clinical competence. Many assessment methods will be present in both training models. However, while time-based models place a strong emphasis on high-stakes written knowledge examinations ("knows") or oral examinations ("knows how"), competency-based models emphasize the need for workplacebased assessments. The goal of these workplace-based assessments is to capture what trainees can do (eg direct observation), which provides opportunities for formative feedback, reflection, and assessment for learning. 
Currently, RCPSC certification in Hematology in Canada requires that residents complete the subspecialty training requirements (specific clinical or laboratory rotations), while demonstrating participation in scholarly research quality assurance, or an educational project. Successful completion of a certification examination is also required. ${ }^{16}$ In addition, the final evaluation report submitted for certification may also include clinical observations (end of rotation evaluations), objective structured clinical examinations (OSCE), feedback from health care professionals, Structured Assessment of a Clinical Encounter (STACER), or other sources of information. Overall, the current certification process aligns more with a traditional model. These methods of assessment are largely weighted towards testing what residents "know" and do not provide opportunities for iterative improvement based on feedback and direct observation. ${ }^{17}$ While performance on end of rotation evaluations and multisource feedback are a critical component of the final certification, there is no clear emphasis on workplace-based assessment. $^{18,19}$

By contrast, the post-Hematology residency portfolio programs in Transfusion Medicine and Adult Thrombosis Medicine provide examples of competency-based programs of assessment. ${ }^{20,21}$ These portfolios are designed to promote assessment for learning by supporting reflective practice and increasing personal responsibility and engagement, while still being used for summative evaluation. ${ }^{22}$ Both of these portfolios include workplacebased assessments through direct observation, submission of consult notes from actual clinical work, and logbooks detailing the diversity of patients seen. These documents are also reviewed with a local supervisor or mentor before submission for approval, which provides an opportunity for formative feedback. As seen in Table 2, many tasks included in the portfolio aim to mirror expectations of independent practice. This aligns with the higher proficiency levels of Miller's Pyramid, "Shows How" and "Does".

There is a paucity of program evaluation data on the impact of these novel portfolios on learning outcomes and faculty engagement. However, a recent program evaluation conducted by the RCPSC suggests that while trainees and program directors see value in standardizing assessment across sites, there may be barriers (discussed further in this manuscript) related to administrative obstacles, a lack of clear guidance, and workload which have resulted in incomplete or delayed portfolio submissions. ${ }^{23}$ Preliminary data from a realist evaluation of the Transfusion Medicine AFC suggests that this portfolio program drives learning by linking assessment tasks explicitly to workplace-based activities that reflect the discipline, and provides more opportunities for formative feedback and reflection.

The post-residency AFC diploma programs model a program of assessment that emphasizes the higher-level "Does" and "Shows How" categories of Miller's Pyramid. As Hematology residency training shifts gradually in Canada to competency-based training, there will be a greater emphasis on direct observation and more frequent, lower-stakes assessments while also continuing to include structured oral and written examinations for licensure. There is a need for ongoing program evaluation activities to determine the impact of these competencybased assessment programs on trainee learning outcomes and faculty engagement.

Table 2 Sample of the RCPSC Objectives for the Transfusion Medicine AFC Program

\begin{tabular}{|l|l|l|}
\hline Milestone & \multicolumn{1}{|c|}{ Standards of Assessment } & $\begin{array}{c}\text { Documents to } \\
\text { Be Submitted }\end{array}$ \\
\hline $\begin{array}{l}\text { Manage the appropriate } \\
\text { utilization of blood products }\end{array}$ & $\begin{array}{l}\text { A description of a specific blood utilization issue and its current clinical practice guideline } \\
\text { for a hospital or a certain patient group, an analysis of the actual blood utilization, and its } \\
\text { compliance with the guidelines. } \\
\text { The submission must demonstrate understanding of the importance of adequate } \\
\text { utilization of blood supplies, attention to safety and quality issues, and adaptation of } \\
\text { practice to different clinical contexts in order to meet specific patient needs. }\end{array}$ & $\begin{array}{l}\text { One of the } \\
\text { following: } \\
\bullet \text { Audit } \\
\bullet \text { Clinical practice } \\
\text { guideline } \\
\bullet \text { Report with } \\
\text { a reflective } \\
\text { critique }\end{array}$ \\
& & \\
\end{tabular}


Table 3 Assessment Methods in Hematology with Respect to Miller's Pyramid

\begin{tabular}{|l|l|l|}
\hline Category & $\begin{array}{l}\text { Examples Commonly Seen in Traditional Training } \\
\text { Models }\end{array}$ & $\begin{array}{l}\text { Examples Commonly Seen in Competency-Based } \\
\text { Models }\end{array}$ \\
\hline Does & $\begin{array}{l}\text { End of rotation evaluations } \\
\text { Multi-source feedback }\end{array}$ & $\begin{array}{l}\text { Direct clinical observation } \\
\text { Portfolio (depending on components) } \\
\text { Case log with reflection (eg, bone marrow, lumbar puncture) } \\
\text { Clinical notes (eg, consult notes, progress notes) } \\
\text { Logbooks (of clinical encounters) }\end{array}$ \\
\hline Shows How \\
& $\begin{array}{l}\text { Objective structured clinical exams } \\
\text { Oral case presentations }\end{array}$ & $\begin{array}{l}\text { Simulated cases } \\
\text { Case summaries** } \\
\text { Order sets** } \\
\text { Standardized Operating Procedures (SOPs)** }\end{array}$ \\
\hline Knows How & Structured oral examination* & $\begin{array}{l}\text { Structured oral examination } \\
\text { Teaching logbook** }\end{array}$ \\
\hline Knows & $\begin{array}{l}\text { Multiple choice or short answer written examination* } \\
\text { Written morphology or hematopathology examination* }\end{array}$ & \begin{tabular}{l} 
Knowledge examination \\
\hline
\end{tabular}
\end{tabular}

Notes: *these components are current high-stakes methods of assessment found in traditional time-based Hematology training programs (eg, Hematology residency training program). **these components are often found in competency-based portfolios (eg, Adult Thrombosis Medicine or Transfusion Medicine Area of Focused Competence).

\section{Challenges to Delivering Residency Education in Hematology Hematology is a Diverse and Rapidly Evolving Specialty}

Hematology is a diverse specialty that encompasses a wide range of laboratory and clinical knowledge spanning both benign and malignant (cancerous) blood disorders, laboratory diagnostics, basic science, quality assurance and resource stewardship. At times, these areas bear little resemblance to one another in terms of their scientific underpinnings or in their day-to-day practice. Malignant Hematology, in particular, is one of the most dynamic fields in clinical medicine due to numerous advances in molecular genetics and immunotherapy. ${ }^{24}$ For malignant blood disorders, treatment algorithms may change as often as once every one or two years, which means that knowledge obtained during training risks being outdated by the time a resident approaches graduation.

Failure to self-regulate learning is common, even among experienced learners, and this may be problematic in a rapidly evolving discipline. ${ }^{25}$ Learners may fail to judge their own learning against established standards, lack the necessary knowledge and skills to monitor their own learning, or struggle to initiate change when their behaviour falls short of expectations. ${ }^{25}$ One way to address this challenge is for residency programs to deliberately promote the development of self-directed learning skills during training. ${ }^{26}$ This "scaffolding" to support self-directed learning can be adapted to local institutional resources and culture. For example, residents could be offered protected time to build a personal learning plan with the help of an academic coach, engage in reflective writing, or manage a portfolio of continuing professional development activities with appropriate supervision and feedback. In Hematology, the ability to search and appraise medical evidence to address clinical issues should be emphasized.

Clinical and laboratory activities in Hematology are becoming increasingly specialized and many hematologists focus their attention on one or two aspects of the discipline (eg Malignant Hematology, Transfusion Medicine, etc). Specialization is also apparent at the institutional level. Canadian academic hospitals vary in terms of their clinical and laboratory expertise; many lack the required resources or patient populations to provide comprehensive training in all aspects of the specialty. For example, novel cellular therapies such as Chimeric Antigen Receptor T-cells (CAR-T), are only offered at a few quaternary care hospitals across the country. Similarly, residents might have limited exposure to specific patient populations depending on local demographics. Nonurban residency programs are often unable to provide residents with sufficient exposure to patients with red cell disorders including sickle cell disease, which are prevalent only in specific ethnic groups. ${ }^{27}$ Visiting electives at other institutions, virtual simulation, or the annual National Hematology Retreat may help address this problem. An online case-bank was 
Table 4 Practical Challenges to Implementing CBME in Hematology. *Solutions Should Be Adapted to Institutional Resources and Culture

\begin{tabular}{|c|c|c|}
\hline & Challenge & Potential Solutions* \\
\hline \multirow{3}{*}{$\begin{array}{l}\text { Residency } \\
\text { program } \\
\text { level }\end{array}$} & $\begin{array}{l}\text { Collecting, storing and interpreting a large } \\
\text { amount of educational data }\end{array}$ & Leverage the use of technology (ie learning analytics system) \\
\hline & $\begin{array}{l}\text { Time and resource investment to creating } \mathrm{CBME} \\
\text { curriculum }\end{array}$ & $\begin{array}{l}\text { Share the responsibility of creating educational materials across multiple } \\
\text { residency programs }\end{array}$ \\
\hline & $\begin{array}{l}\text { Shift away from time-based curriculum impacting } \\
\text { clinical service/workforce planning }\end{array}$ & $\begin{array}{l}\text { Preserve the block rotation schedule to make resident scheduling more } \\
\text { predictable }\end{array}$ \\
\hline \multirow[t]{3}{*}{ Faculty level } & Additional time needed for direct observation & $\begin{array}{l}\text { Distribute the responsibility of direct observation across all faculty members } \\
\text { Use simulation when appropriate } \\
\text { Encourage participation of senior residents, fellows, and Chief Residents when } \\
\text { appropriate }\end{array}$ \\
\hline & $\begin{array}{l}\text { Lack of capacity to take on additional educational } \\
\text { roles (eg academic coach) }\end{array}$ & $\begin{array}{l}\text { Incentivize faculty members to take on CBME roles (eg credit toward tenure } \\
\text { and promotion, financial remuneration) }\end{array}$ \\
\hline & Theoretical criticisms about CBME & $\begin{array}{l}\text { Encourage and incentivize participation in high-quality faculty development } \\
\text { activities } \\
\text { Regular and honest dialogue about pros/cons of CBME and potential solutions }\end{array}$ \\
\hline \multirow[t]{2}{*}{ Resident level } & $\begin{array}{l}\text { Maladaptive assumptions about learning (fixed } \\
\text { mindset) }\end{array}$ & $\begin{array}{l}\text { Foster a psychologically safe learning environment } \\
\text { Reward effort as well as achievement } \\
\text { Establish procedures that place value on feedback at all levels of the } \\
\text { organization }\end{array}$ \\
\hline & Failure to self-regulate learning & $\begin{array}{l}\text { Integrate opportunities for self-directed learning throughout the residency } \\
\text { program (eg academic coach, portfolio, reflective writing, etc.) }\end{array}$ \\
\hline
\end{tabular}

recently developed to help educate Canadian residents on comprehensive care for patients with sickle cell disease who might otherwise have few opportunities to see these patients over the course of their training. ${ }^{28}$

\section{Practical Challenges to Implementing Competency Based Medical Education}

CBME holds promise for improving postgraduate training but there are practical challenges that must be overcome for successful implementation (see Table 4). First, residency education is only one of numerous competing priorities for academic health science organizations. CBME emphasizes individual and flexible learning plans rather than time spent in the clinical environment. As a result, it has the potential to disrupt resident scheduling and workforce planning. ${ }^{29}$ CBME also demands a shift in clinical supervision from passive and indirect observation to direct observation and in-the-moment coaching and feedback. Direct observation takes more time and may compromise the efficiency of delivering patient care in a busy clinical setting.
To address these problems, most Canadian Hematology residency programs are expected to layer the principles of CBME on top of their existing time-based curricula. An example of workflow in a competence based medical education curriculum is outlined in Figure 2.

Second, planning and administering a competencybased curriculum is both time and resource intensive. The RCPSC spent more than eighteen months drafting twenty-two Entrustable Professional Activities (EPAs) that define the core tasks of the discipline and revising national accreditation standards. This process required lengthy consultation with all Canadian Hematology Residency Program Directors who helped to establish consensus on the new curriculum.

Clinical supervisors fear that a shift to CBME means more time spent on administrative tasks including documenting observations and filling out evaluations of workplace performance. ${ }^{29,30}$ The massive amount of educational data generated by a competency-based curriculum must then be collected, organized and analyzed 


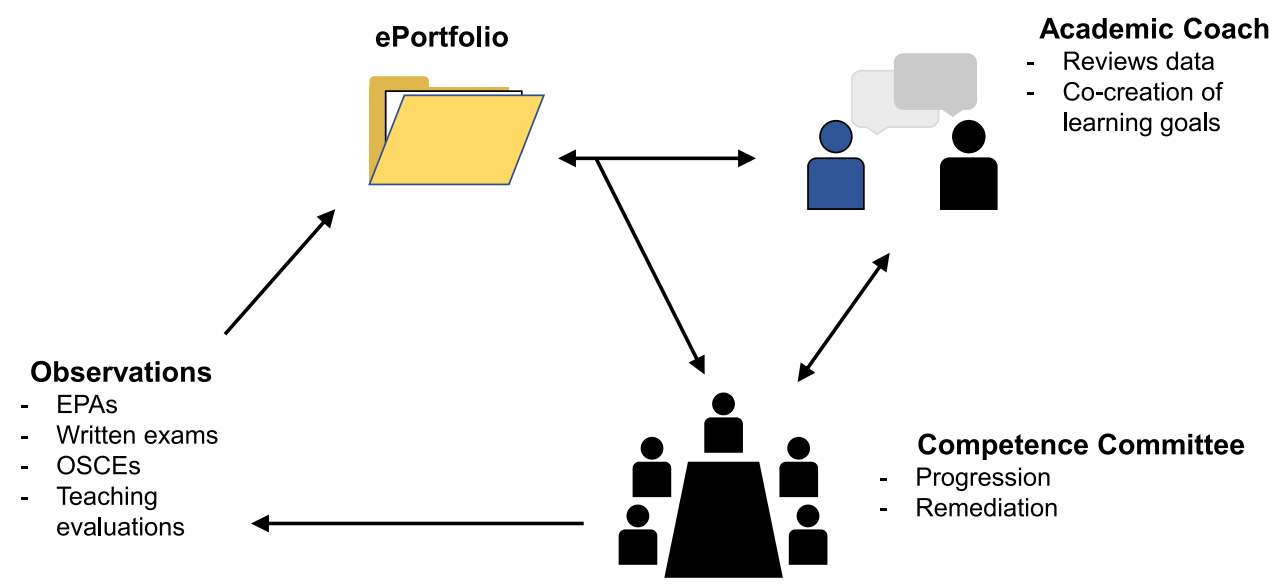

Figure 2 Workflow of competency-based medical education.

at regular intervals. Learning analytics software can help alleviate some of this administrative burden, but unless this software is purposefully and thoughtfully designed it might have the opposite effect. Learning analytics also have the potential to engender inequality, diminish student agency and breach student privacy. ${ }^{31}$ Greller and Drachsler $^{32}$ propose a framework for evaluating the appropriateness of a learning analytics system that includes: the tool's impact on stakeholders, its purpose, the data that is to be collected, the algorithms that are used, adherence to external regulation and privacy laws, and ensuring that end-users are sufficiently trained to make sense of the aggregate data without introducing bias. $^{32}$

Finally, in order to realize the full potential of CBME, learners must shift from a fixed to a growth mindset. Dweck and colleagues ${ }^{33}$ propose that learners hold implicit assumptions about the degree to which intelligence and other traits are innate or can be improved by purposeful effort. ${ }^{34}$ Learners with a growth mindset embrace challenge, persist in the face of obstacles, conceptualize feedback as an opportunity for growth and focus on mastery rather than performance. ${ }^{35}$ Currently, assessment in medical education tends to value achievement over growth. Learner, educator, and institution-level strategies have been proposed to tip the balance toward a growth mindset. ${ }^{35}$ The most frequently described interventions involve teaching learners about the growth mindset and encouraging them to set goals that focus on their progress (effort) rather than their performance (achievement). Educators can role-model growth mindset behaviours, prompt learner reflection, and create psychologically safe learning environments so that learners are in a position to internalize constructive feedback without feeling judgment or shame. At the institutional level, universities can establish procedures that integrate feedback, development, and growth at all levels of the organization.

\section{Theoretical Challenges to Delivering Competency-Based Medical Education}

Uptake and enthusiasm for CBME may be dampened by conceptual and theoretical criticisms. Critics of CBME argue that clinical competence is "more than the sum of its parts" and that breaking down professional tasks into sub-competencies is inherently a reductionist approach to training a specialist. Other criticisms are that competencies tend to exist in isolation from the clinical context and are often biased towards behaviours that are easily measured, rather than more meaningful attributes such as humility, responsibility and reflection. ${ }^{29}$

On the other hand, the opportunity to define the core activities of a hematologist in terms of EPAs can help emphasize uniquely important aspects of the profession, such as quality improvement, resource stewardship and advocating for special patient populations (eg racialized or transgender patients). The concrete nature of EPAs and the fact that they can be broken down into observable milestones can actually help evaluators diagnose poor performance and focus their feedback on the most problematic sub-competencies. ${ }^{29}$ EPA assessments can also be contextualized and grounded in an authentic clinical context through the use of narrative feedback. 


\section{The Impact of COVID-I 9}

The COVID-19 pandemic has impacted all levels of medical training and areas of practice. Like all clinical programs, Hematology training programs were forced to rapidly redesign curricula to ensure trainee, patient and faculty safety while continuing to deliver required learning content and opportunities. Programs have adopted virtual teaching rounds and shifted to mixed clinical exposure with some patients seen in-person and others virtually. Laboratory teaching sessions were offered virtually and/ or in-person depending on site, topic and teacher. Assessment was also impacted; in 2020, Hematology candidates completed only the written component of their certification exam. In 2021, the exam similarly consisted of one three-hour paper comprised of short-answer questions. The National Hematology Retreat has also shifted to a virtual platform to continue to support trainee learning.

Hematology services have been uniquely positioned to address many COVID-19-specific pathophysiologic impacts. Trainees have learned in real-time the importance of rapid critical appraisal of emerging evidence for COVID-19-related thrombotic events and their treatment/ prevention, COVID-19 convalescent plasma utilization and vaccine induced immune thrombotic thrombocytopenia. Trainees have been a part of research efforts in these areas in addition to policy development and implementation and patient education. By living through this tumultuous period of time, trainees are learning first-hand not only the importance of, but also the application of critical appraisal, quality improvement, public health advocacy and social determinants of health, ${ }^{36}$ all of which are integral to the function of a successful hematologist.

\section{Future Directions}

The future of medical education in Hematology and Transfusion Medicine is dynamic and changes have been accelerated by the COVID-19 pandemic. Virtual care has implications for trainees as they transition to independent practice. As risk from COVID-19 diminishes with increased vaccine-uptake and other pandemiccontainment strategies are implemented, there may be an ongoing role for virtual care or telemedicine in Hematology. Canadian physicians from any discipline are expected to maintain the same standard of care irrespective of whether a patient visit happens virtually or in-person. ${ }^{37}$ In addition to considering medicolegal and ethical aspects of delivering care virtually, trainees must also adapt their communication skills to develop a therapeutic relationship with patients in a virtual environment. Many nonprocedural EPAs could be adapted to virtual patient encounters and allow trainees to receive targeted feedback.

Another trend in Hematology residency education is an emphasis on comprehensive and continuous program evaluation. The RCPSC expects that residency programs adopt evaluation processes that are: 1) systematic - involving all stakeholders and employing measuring instruments that are fit-for-purpose; 2) structural - embedded within the procedures of the residency program and not simply done on an ad-hoc basis or in response to accreditation; and 3) integrated into regular work patterns. These expectations are broadly consistent with the concept of "total quality management" where program evaluation not only serves as a means to detect problems with a training program but also places emphasis on continuous quality improvement. ${ }^{38,39}$

Whether CBME improves residency education and patient outcomes is largely unknown. To guide and encourage program evaluation, the RCPSC runs multiple initiatives including a CBME Program Evaluation Forum. The Emergency Medicine program at Queen's University in Canada was one of the first programs to adopt CBME and it was recently evaluated through case-study methodology. ${ }^{40}$ The evaluation identified important issues and reinforced the need for ongoing cycles of evaluation and program development. ${ }^{40}$ Recent studies have also emphasized the importance of program evaluation at both a local level and across programs at a national level. ${ }^{41}$

\section{Conclusion}

In summary, medical education within Hematology and Transfusion Medicine is dynamic and there is a constant push to improve and optimize. Hematology residency programs will soon shift from a traditional time-based curriculum to CBME. Assessment methods must be adapted to emphasize direct observation in the workplace, coaching and feedback. There has been growing interest in comprehensive program evaluation to encourage continuous quality improvement. A number of adaptations to Hematology curricula have and will continue to be made in response to the COVID-19 pandemic.

\section{Acknowledgment}

The authors wish to thank Dr. Luke Chen for providing valuable feedback and insights during preparation of the manuscript. 


\section{Disclosure}

Marissa Laureano receives funding through Canadian Blood Services. Siraj Mithoowani has received personal fees from Leo Pharma. Eric K. Tseng has received honoraria from Medison Canada. Michelle P. Zeller has received honoraria from American Society of Hematology, Pfizer, Pharmacosmos; Advisory Board for Pfizer; Research funding from CBS, Canadian Institutes of Health Research and Pfizer Global Medical Grants; none of these relationships impacted the content of this review. The authors report no other conflicts of interest in this work.

\section{References}

1. Iobst WF, Sherbino J, Cate OT, et al. Competency-based medical education in postgraduate medical education. Med Teach. 2010;32 (8):651-656. doi:10.3109/0142159X.2010.500709

2. The Royal College of Physicians and Surgeons of Canada. All rights reserved. Objectives of Training in Hematology | (C) 2015 Available from: https://www.royalcollege.ca/rcsite/documents/ibd/hematology_ otr e. Accessed May 15, 2021.

3. Frank JR, Danoff D. The CanMEDS initiative: implementing an outcomes-based framework of physician competencies. Med Teach. 2007;29(7):642-647. doi:10.1080/01421590701746983

4. ACGME. ACGME program requirements for graduate medical education in hematology and medical oncology; 2020. Available from: https://www.acgme.org/Portals/0/PFAssets/ProgramRequirements/ 155_HematologyAndMedicalOncology_2020.pdf?ver=2020-06-29162353-163. Accessed September 6, 2021.

5. Carraccio CL, Englander R. From Flexner to competencies: reflections on a decade and the journey ahead. Acad Med. 2013;88 (8):1067-1073. doi:10.1097/ACM.0b013e318299396f

6. Carraccio C, Englander R, Van Melle E, et al. Advancing competency-based medical education: a charter for clinician-educators. Acad Med J Assoc Am Med Coll. 2016;91 (5):645-649. doi:10.1097/ACM.0000000000001048

7. The Royal College of Physicians and Surgeons of Canada. Area of Focused Competence (AFC) diploma. Available from: https:// www.royalcollege.ca/rcsite/credentials-exams/exam-eligibility /areas-focussed-competence-afc-diploma-e. Accessed May 15, 2021.

8. Zeller MP, Sherbino J, Whitman L, Skeate R, Arnold DM. Design and implementation of a competency-based transfusion medicine training program in Canada. Transfus Med Rev. 2016;30(1):30-36. doi:10.1016/j.tmrv.2015.11.001

9. Tseng EK, Lane S, Patterson H, Skeate R, Kuper A, Rojas D, Zeller M. How do subspecialty portfolios work, for whom, and why? A realist evaluation of the transfusion medicine area of focused competence. Can Med Educ J. 2021 Feb;12(1):e120-e179.

10. Schuwirth LWT, Van Der Vleuten CPM. General overview of the theories used in assessment: AMEE Guide No. 57. Med Teach. 2011;33(10):783-797. doi:10.3109/0142159X.2011.611022

11. Van Der Vleuten CPM, Schuwirth LWT, Driessen EW, et al. A model for programmatic assessment fit for purpose. Med Teach. 2012;34 (3):205-214. doi:10.3109/0142159X.2012.652239

12. Martin M, Vashisht B, Frezza E, et al. Competency-based instruction in critical invasive skills improves both resident performance and patient safety. Surgery. 1998;124(2):313-317. doi:10.1016/S00396060(98)70136-9
13. Bisgaard CH, Rubak SLM, Rodt SA, Petersen JAK, Musaeus P. The effects of graduate competency-based education and mastery learning on patient care and return on investment: a narrative review of basic anesthetic procedures. BMC Med Educ. 2018;18(1):154. doi:10.1186/ s12909-018-1262-7

14. Nousiainen MT, Mironova P, Hynes M, et al. Eight-year outcomes of a competency-based residency training program in orthopedic surgery. Med Teach. 2018;40(10):1042-1054. doi:10.1080/014215 9X.2017.1421751

15. Pangaro L, Ten cate O. Frameworks for learner assessment in medicine: AMEE Guide No. 78. Med Teach. 2013;35(6):1197-1210. doi:10.3109/0142159X.2013.788789

16. The Royal College of Physicians and Surgeons of Canada. Subspecialty training requirements in hematology. Available from: https://www.royalcollege.ca/rcsite/documents/ibd/hematology_str_e. pdf. Accessed March 4, 2021.

17. Norcini J, Anderson B, Bollela V, et al. Criteria for good assessment: consensus statement and recommendations from the Ottawa 2010 conference. Med Teach. 2011;33(3):206-214. doi:10.3109/014215 9X.2011.551559

18. Norcini J, Burch V. Workplace-based assessment as an educational tool: AMEE Guide No. 31. Med Teach. 2007;29(9-10):855-871. doi:10.1080/01421590701775453

19. Dornan T. Workplace learning. Perspect Med Educ. 2012;1(1):15-23. doi:10.1007/s40037-012-0005-4

20. The Royal College of Physicians and Surgeons of Canada. Competency training requirements for the area of focused competence in transfusion medicine. Available from: https://www.royalcol lege.ca/rcsite/documents/ibd/transfusion-medicine-afc-sa-e.pdf. Accessed March 4, 2021.

21. The Royal College of Physicians and Surgeons of Canada. Competency training requirements for the area of focused competence in adult thrombosis medicine. Available from: https://www. royalcollege.ca/rcsite/documents/ibd/transfusion-medicine-afc-sa-e. pdf. Accessed March 4, 2021.

22. Tochel C, Haig A, Hesketh A, et al. The effectiveness of portfolios for post-graduate assessment and education: BEME Guide No 12 . Med Teach. 2009;31(4):299-318. doi:10.1080/01421590902883056

23. The Royal College of Physicians and Surgeons of Canada. Areas of focused competence program evaluation: overview and key findings. Available from: https://www.royalcollege.ca/rcsite/documents/special ties/afc-pe-results-e.pdf. Accessed March 4, 2021.

24. Balatzenko G, Guenova M. Introductory Chapter: Hematology in Times of Precision and Innovation. IntechOpen; 2018. doi:10.5772/ intechopen.76849

25. Kirschner PA, Merriënboer van JJG. Do learners really know best? urban legends in education. Educ Psychol. 2013;48(3):169-183. doi:10.1080/00461520.2013.804395

26. van Merriënboer J, Kirschner PA Ten steps to complex learning: a systematic approach to four-component. Available from: https:// www.routledge.com/Ten-Steps-to-Complex-Learning-A-SystematicApproach-to-Four-Component-Instructional/Merrienboer-Kirschner /p/book/9781138080805. Accessed May 16, 2021.

27. CDC. Data \& statistics on sickle cell disease. Centers for Disease Control and Prevention. December 16, 2020. Available from: https://www.cdc.gov/ncbddd/sicklecell/data.html. Accessed May 16, 2021.

28. Verhovsek M, Hou C, Azzam M, et al. Pilot study of online learning modules for hemoglobinopathy education in Canadian hematology training programs. Blood. 2016;128(22):314. doi:10.1182/blood. V128.22.314.314

29. Hawkins RE, Welcher CM, Holmboe ES, et al. Implementation of competency-based medical education: are we addressing the concerns and challenges? Med Educ. 2015;49(11):1086-1102. doi:10.1111/medu. 12831 
30. Malone K, Supri S. A critical time for medical education: the perils of competence-based reform of the curriculum. Adv Health Sci Educ Theory Pract. 2012;17(2):241-246. doi:10.1007/s10459-010-9247-2

31. Francis P, Broughan C, Foster C, Wilson C. Thinking critically about learning analytics, student outcomes, and equity of attainment. Assess Eval High Educ. 2020;45(6):811-821. doi:10.1080/02602938.2019. 1691975

32. Greller W, Drachsler H. Translating learning into numbers: a generic framework for learning analytics. J Educ Technol Soc. 2012;15(3):42-57.

33. Dweck CS. Mindset: The New Psychology of Success. Random House; 2006

34. Osman NY, Sloane DE, Hirsh DA. When I say ... growth mindset. Med Educ. 2020;54(8):694-695. doi:10.1111/medu.14168

35 . A review to characterise and map the growth mindset theory in health professions education. Wolcott - Medical Education - Wiley Online Library; 2021. Available from: https://onlinelibrary.wiley.com/doi/ abs/10.1111/medu.14381?af=R. Accessed May 16, 2021.

36. Lucey CR, Johnston SC. The transformational effects of COVID-19 on medical education. JAMA. 2020;324(11):1033. doi:10.1001/jama. 2020.14136

37. CPSO. Telemedicine. Available from: https://www.cpso.on.ca/ Physicians/Policies-Guidance/Policies/Telemedicine. Accessed May 16,2021

38. Dolmans DHJM, Wolfhagen HAP, Scherpbier AJJA. From quality assurance to total quality management: how can quality assurance result in continuous improvement in health professions education? Educ Health Abingdon Engl. 2003;16(2):210-217. doi:10.1080/ 1357628031000116899
39. Dolmans D, Stalmeijer R, van Berkel H, Wolfhagen I. Medical Education: Theory and Practice. Churchill Livingstone: Quality Assurance of Teaching and Learning: Enhancing the Quality Culture; 2011.

40. Hall AK, Rich J, Dagnone JD, et al. It's a marathon, not a sprint: rapid evaluation of competency-based medical education program implementation. Acad Med J Assoc Am Med Coll. 2020;95(5): 786-793. doi:10.1097/ACM.0000000000003040

41. Thoma B, Hall AK, Clark K, et al. Evaluation of a national competency-based assessment system in emergency medicine: a CanDREAM study. J Grad Med Educ. 2020;12(4):425-434. doi:10.4300/JGME-D-19-00803.1

42. Epstein RM, Hundert EM. Defining and assessing professional competence. JAMA. 2002;287(2):226-235. doi:10.1001/jama.287. 2.226

43. Frank JR, Snell LS, Cate OT, et al. Competency-based medical education: theory to practice. Med Teach. 2010;32(8):638-645. doi:10.3109/0142159X.2010.501190

44. Ten Cate O. Entrustability of professional activities and competency-based training. Med Educ. 2005;39(12):1176-1177. doi:10.1111/j.1365-2929.2005.02341.x

45. Driessen EW, Heeneman S, van der Vleuten CPM. Portfolios, projects, and theses. In: A Practical Guide for Medical Teachers. 5th ed. Elsevier; 2017:274-280.

46. The Royal College of Physicians and Surgeons of Canada. What is CBD? Available from: https://www.royalcollege.ca/rcsite/cbd/what-is -cbd-e. Accessed May 16, 2021.
Advances in Medical Education and Practice

\section{Publish your work in this journal}

Advances in Medical Education and Practice is an international, peerreviewed, open access journal that aims to present and publish research on Medical Education covering medical, dental, nursing and allied health care professional education. The journal covers undergraduate education, postgraduate training and continuing medical education
Dovepress

including emerging trends and innovative models linking education, research, and health care services. The manuscript management system is completely online and includes a very quick and fair peer-review system. Visit http://www.dovepress.com/testimonials.php to read real quotes from published authors. 